\title{
DOLENJSKA SUBSOIL STONE FORESTS AND OTHER KARST PHENOMENA DISCOVERED DURING THE CONSTRUCTION OF THE HRASTJE - LEŠNICA MOTORWAY SECTION (SLOVENIA)
}

\author{
DOLENJSKI PODTALNI KAMNITI GOZDOVI IN DRUGI KRAŠKI \\ POJAVI, ODKRITI PRI GRADNJI AVTOCESTNEGA ODSEKA \\ HRASTJE - LEŠNICA
}

\author{
Martin KNEZ ${ }^{1} \&$ Tadej SLABE ${ }^{1}$
}

\begin{abstract}
UDC 551.435.8(497.4)

Martin Knez \& Tadej Slabe: Dolenjska subsoil stone forests and other karst phenomena discovered during the construction of the Hrastje - Lešnica motorway section

This paper explains the investigation of shallow and sedimentcovered areas of the Dolenjska karst discovered during the construction of the motorway section between the villages of Hrastje and Lešnica. Research done during construction has again proved to be very useful; we came to numerous and augmentative conclusions about the development of karst features typical of the Dolenjska region. Again the importance of the participation of karst researchers in planning major activities concerning the karst and in monitoring the work was demonstrated. We have researched the unique features of the karst surface marked mostly by large areas of stone forests and characteristic karstification below the thick sediment beds.

Key words: stone forests, subsoil formation of carbonate rock, Dolenjska karst, Slovenia.
\end{abstract}

Izvleček

UDK 551.435.8(497.4)

Martin Knez \& Tadej Slabe: Dolenjski podtalni kamniti gozdovi in drugi kraški pojavi, odkriti pri gradnji avtocestnega odseka Hrastje - Lešnica

Članek obravnava raziskave plitvega dolenjskega krasa med gradnjo avtocestnega odseka med vasema Hrastje in Lešnica. Raziskave med gradnjo so se tudi tokrat izkazale kot zelo koristne, saj smo prišli do številnih novih in dopolnjujočih zaključkov o razvoju tega, za Dolenjsko značilnega krasa. Ne nazadnje se je spet izpostavil pomen sodelovanja krasoslovcev pri načrtovanju večjih posegov v kraško površje in spremljava del. Raziskovali smo svojevrstno oblikovanost kraškega površja, ki jo predstavljajo predvsem velike površine kamnitih gozdov ter značilno zakrasevanje pod debelimi plastmi naplavin.

Ključne besede: kamniti gozdovi, podtalno oblikovanje karbonatnih kamnin, dolenjski kras, Slovenija.

\section{INTRODUCTION}

The monitoring of the construction of the Dolenjska motorway by karst researchers has again proved to be of great value in the exploration of our natural heritage through the deepening of our knowledge about the formation and development of this part of the Slovenian karst. This characteristic subsoil karst surface was formed under a cover of sediment of varying depth. Subsoil formation of carbonate rock also marks the entire epi-karst and vadose zone. The surface is carved into subsoil stone for- ests (Figs. 1, 2), the surfaces of the karren are smaller and numerous hollow shafts are filled with fine-grained sediment. The outstanding characteristics of the karst surface are primarily the result of large surfaces of stone forests, which are difficult to detect prior to earthwork or geophysical research. Most of the surface is above the underground water level. The only exception is the motorway section at Hrastje, which was not fully uncovered due to the construction method and because lower road beds

${ }^{1}$ Karst Research Institute, ZRC SAZU, Titov trg 2, SI-6230 Postojna, Slovenia, e-mail: knez@zrc-sazu.si, slabe@zrc-sazu.si

Prejeto/Received: 05.09.2006 


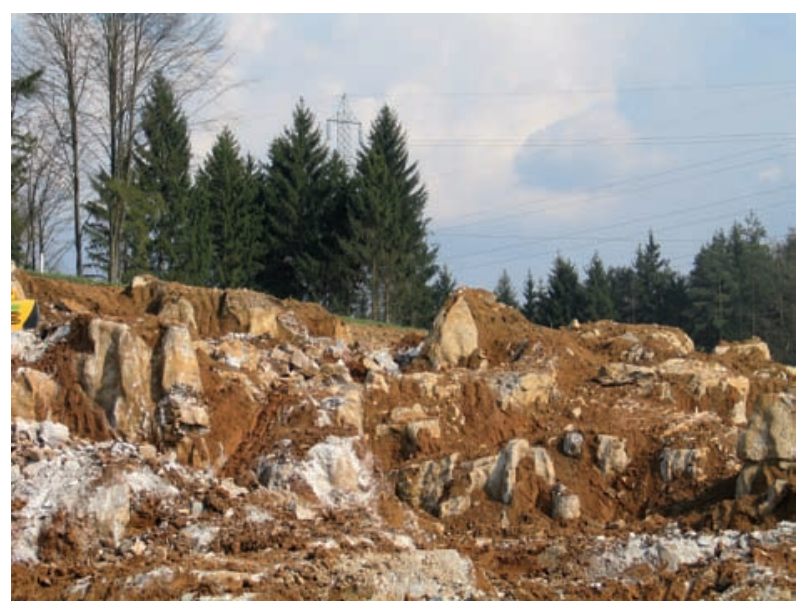

Fig. 1: Uncovering of subsoil stone forest.

Sl. 1: Razkrivanje podtalnega kamitega gozda.

were put upon a special grounding. For this reason we could only research the karst formations that had been shaped by water percolation through the karst surface. We did not find the characteristic subsoil karren as those discovered during the earthwork at Bič, which were also formed by the fluctuation of underground water (Knez et al., 2004). Karst features discovered during construction

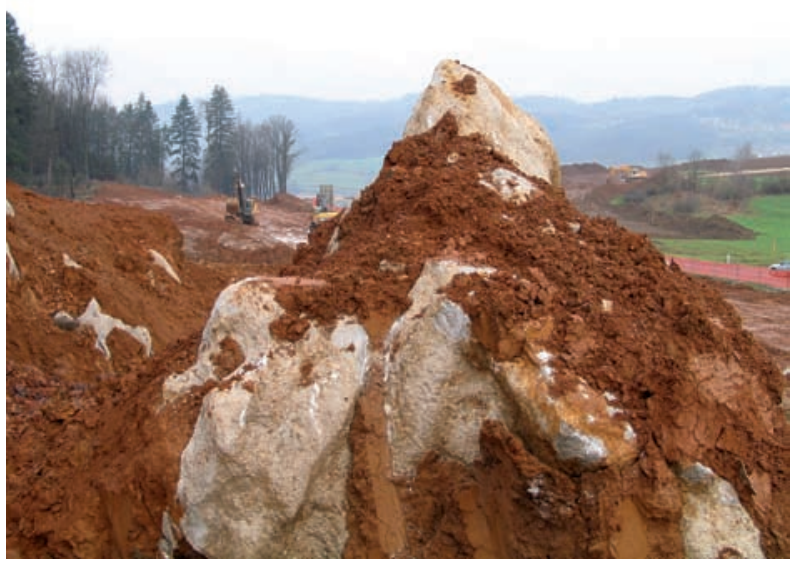

Fig. 2: Subsoil shaped pillar of stone forest.

Sl. 2: Podtalno oblikovan steber kamnitega gozda.

work give us insight into the characteristics and manner of formation of the karst in the wider area of southern Slovenia; they thus unveil yet another characteristic of our karstic natural heritage that is hidden from view, but which also provides guidelines for planning activities on the surface.

\section{THE MOTORWAY ROUTE AND THE MAIN CHARACTERISTICS OF THE LANDSCAPE}

The north-eastern part of the motorway section starts in the vicinity of a swallow hole of the Igmanca stream near the villages of Hrastje, Dolenja vas and Šentjurij and pass the village of Selo along characteristic Dolenjska lowland. Lateral, changing and relatively thick beds of sediment and soil cover the land. The underground water is close to the surface of the predominant fluviokarst. Here we find individual karstic features, among them minor swallow holes, esatavellas and, to a lesser extent, an outcrop of carbonate rock. The terrain rises slightly towards the Strmec and Dobrava hills, where the road climbs more steeply and soon after the pass drops towards the Krka River. We have detected thinner sediment beds and frequent outcropping of karstified rock, which mostly disintegrates into small fragments. There is less surface water at that location since it flows into the subsoil relatively quickly due to the inclination of the terrain, the thin sediment beds and fragmentary cover of disintegrated rock. The stone forests and karren, which reach various depths, are composed of compact and also tectonically very crushed rock. Where the rock is not crushed and where compact blocks of limestone occur between the cracks, we noticed stone teeth on the surface. During the earthwork, these had in many cases revealed themselves as real stone pillars. Where the rock was tectonically cracked or crushed, we did not find karren on the surface; however, at some locations rudimentary stone teeth hidden beneath the soil immediately disintegrated during earthwork. Between the Brezovica and Lešnica hills we again find typical shallow Dolenjska karst with its underground level close to the surface, and its characteristic collapses and sinkholes. A rare network of streams is formed on the surface, but a substantial part of the source and side channels do not have permanent flows. Minor springs of underground water are frequent and flow along narrow, corroded cracks in the rock. Surface and subsoil karst features are rare. The surrounding valleys are dry for most of the year, and streams and floods only occur after downpours. Percolating water feeds small but permanent sources. Fluctuation of the flow from these sources is minimal and rarely more abundant, which reflects greater permeability and cavernosity. Underground water flow is close to the surface, for which reason karst formations such as this are called "shallow karst".

Thick beds of Plioquaternary sediments on carbonate rock, especially on a moist surface, are usually acid. It 
is not yet fully understood whether these sediments are autochthonous or brought from the nearby dolomite surroundings (Gams 2004). After comparison with the circumstances in tropical karst, the opinion developed that in these valleys the thick layers of disintegrated material could have been preserved only because of the high underground water level and poor erosion, and thus developed into subsoil karst.

\section{GEOLOGICAL CHARACTERISTICS OF THE AREA}

The motorway route between Hrastje and Lešnica runs, for the most part, on Jurassic (Lower Malm) rock. In some cases it also crosses Plioquaternary sediment and alluvial river sediment. From the geo-tectonic aspect it belongs to the Outer Dinarids, characterised by its block structure and the Dinaric orientation of the faults and alignment of the folds. A covered fault runs along the western side of the road section. The anticline fold of the Upper Jurassic beds run in the Dinaric sense from Dolenja Nemška vas on the northwest to Novo mesto on the southeast. The road mostly runs along its northern flank. The dip of the beds changes, but the general direction is towards the northeast. We find various micro and macro fauna in the rock along the route as well as macro flora in its central part.

The Upper Jurassic beds to the north border on Upper Cretaceous brown and green marl, sandy marl, marly limestone and grey and red platy limestone with intrusions of breccia. To the south they border on Plioquaternary brown clay sediments. North of Prečna we find a minor area of upper Triassic stratified and un-stratified grey dolomite.

According to a geo-tectonic survey map (Pleničar \& Premru 1977) the area of the motorway section lies on the Novo mesto block. Its northern part is a transition between the Sava folds and the Dolenjsko-Notranjska block. The oldest rock here is Middle and Upper Triassic dolomite over which Jurassic limestone had been discordantly deposited and over Cretaceous pelagic rock. The characteristics of the terrain are synclines and anticlines running in the Dinaric direction, which at places diverge from their characteristic orientation.

The Jurassic beds in the Novo mesto surroundings are generally composed of light grey limestone that lies on Cordevol Upper Triassic dolomite and forms the base for their discordantly deposited Upper Cretaceous pelagic sediments (Pleničar \& Premru 1977).

The Lower Malm rocks are strongly varied along the motorway section north of Novo mesto (Pleničar et al., 1976). In the northern biostratigraphic zone and southern biostratigraphic zone we find alternating white and grey limestone, oolitic limestone, reef limestone with hydrozoans and bedded limestone with chert.

The northern biostratigraphic zone can in a broader sense be found on the motorway section between Poljane and Mali Slatnik, east of Novo mesto (Pleničar \& Premru 1977), which mostly runs north-east of this motorway section. Here light-grey, un-stratified reef limestone and large-grained reef breccia are predominant. Here and there we can find dark grey and almost un-stratified limestone between these beds. Rich hydrozoan fauna can be found in the un-stratified limestone. Occasionally we also found platy limestone with chert.

Along the south-eastern parts we are most probably following a middle biostratigraphic zone, which is lithologically similar to the northern biostratigraphic zone; hydrozoans are not as present in the rock. Oolitic limestone can also be found in the reef limestone (Pleničar \& Premru 1977). Corals appear in some places. According to the geological map and it's commentary (Pleničar et al., 1976; Pleničar \& Premru 1977), southern biostratigraphic rock characterised by grey, dense and oolitic bedded limestone, does not exist along the route.

In the Plioquaternary sediments southwest of Mačkovec we find an outcrop of bentonite clay. The clay lies in the pockets of Triassic dolomite and in the Jurassic limestone. At places it is deposited in beds of a total thickness of up to $12 \mathrm{~m}$.

\section{KARREN SURFACE}

Most of the surface of the higher-lying land is karren. The bottoms of dales are covered by sediment beds. Two types of karren can be clearly distinguished. Karren in their original meaning occur in areas that are not covered by sediment, but with thin layer of soil. They cover the major part of the surface. The carbonate rock is dissected along the cracks, and on the rock we can detect the traces of its former a) subsoil formation (Slabe 1999; Slabe \& 
Knez 2004) - these are relatively few, and b) indirectly transformed by precipitation, the surface was overgrown and c) finely shaped by bio-corrosive factors. The surface was mostly forested. Such karren existed on the surface of the cone in the dale at the beginning of the motorway section.

Especially in the area of the Strmec and Dobrava hills we observed well-expressed bio-corrosive activities on numerous karren outcrops of carbonate rock (Fig. 3 ). The rock was more diluted by bio-corrosion on the shadier sides. Moss mostly grows there while lichen can also be found on areas exposed to the sun. Bio-corrosive processes do not take place equally on the entire surface of the rock, but selectively. Most probably lithologically slightly different clasts in crushed and then cemented rock are diluted to various depths or else there are different organisms in the various neighbouring clasts. The contact areas between the various clasts are especially corroded, in some spots up to several mm deep.

The major part of the forest-covered surface was dissected mainly by individual rocks of various sizes with partially similar traces of formation to the karren described above. They are frequently defined by fun-

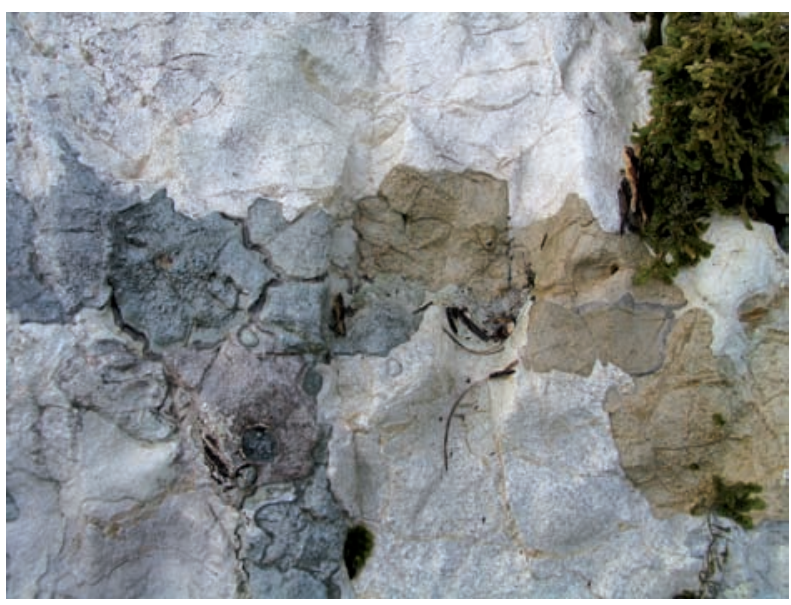

Fig. 3: Bio-corrosively etched surface of karren.

Sl. 3: Biokorozisko razjedena površina škrapelj.

nel-shaped mouths of larger subsoil channels. The rocks reach up to one to two metres in height, with a narrowing on top and with large areas of soil between them. The earthwork uncovered them as the tips of the larger areas of stone forests.

\section{SUBSOIL STONE FORESTS}

Relatively large areas of subsoil stone forests illustrate the manner and long-lasting subsoil formation of this part of the karst surface, covered by fine-grained sediment and soil. The stone pillars are completely covered by the sediment and soil, or their tips protruding on the surface.

The configuration of the surface includes smaller or larger dolinas (Fig. 4). The largest have a diameter of several tens of metres. Some are filled with grey clay, the

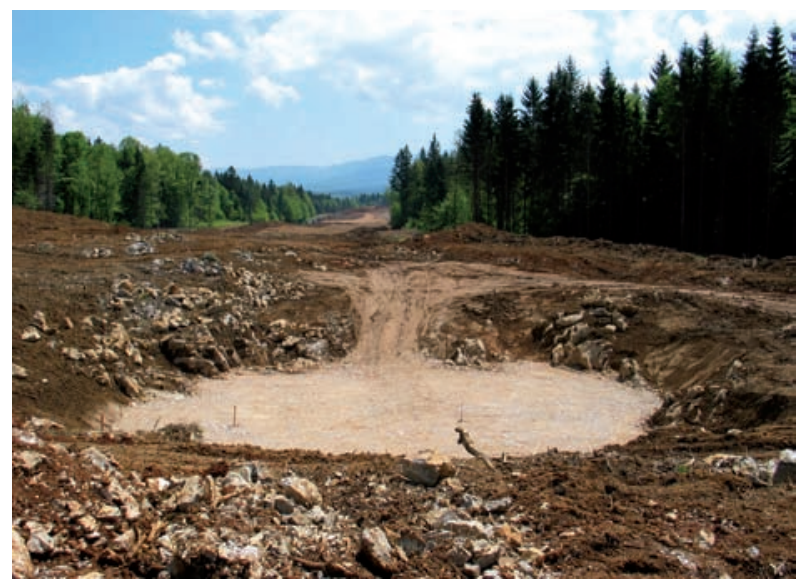

Fig. 4: Filling of dolina with gravel.

Sl. 4: Zapolnjevanje vrtače z gruščem. origins of which we are still investigating. Both are dissected by subsoil stone forests.

The subsoil stone forests are composed of a dense network of more or less thickset and pointed pillars, which reach up to 8 , sometimes even 10 metres, although most are lower. The narrower pillars with a diameter of one to two metres have sharp or rounded spire (Fig. 5), while the thickest ones reaching up to ten metres (Fig. 6)

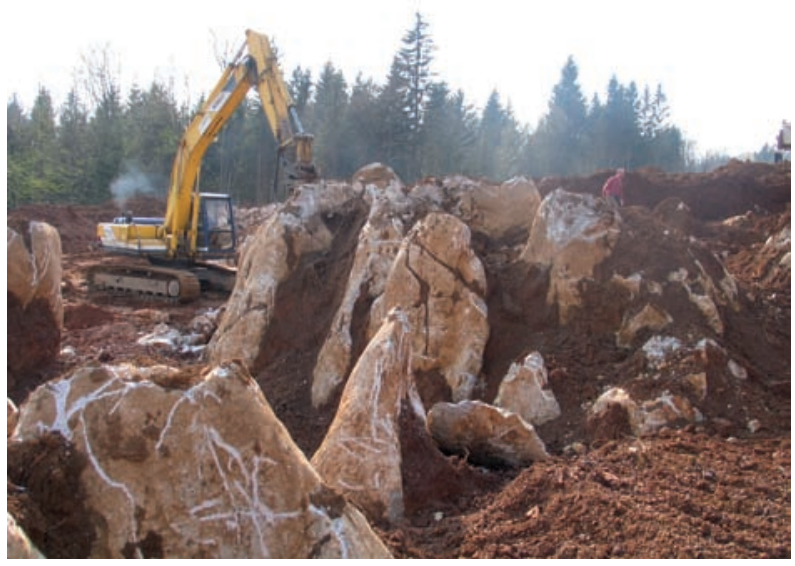

Fig. 5: Pointed tops of narrower pillars.

Sl. 5: Kničasti vrhovi ožjih stebrov. 


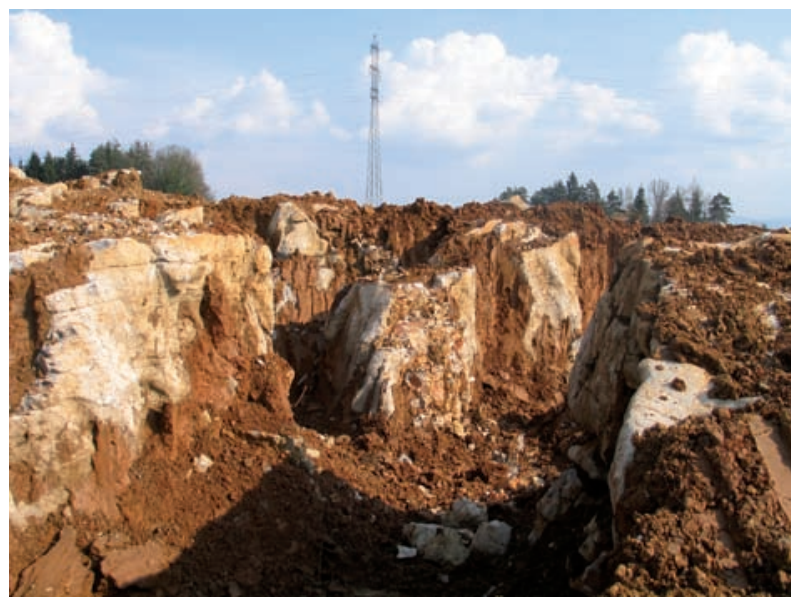

Fig. 6: Wider stone pillars.

Sl. 6: Obsežnejši podtalni stebri.

in width have one or more spires or their tops are composed of more or less curved crests. Among them in most parts are funnel mouths of the perpendicular subsoil channels or horizontal subsoil channels.

Subsoil rock features predominate in the rock relief of the pillars (Slabe 1999; Slabe \& Knez 2004), which indicates gravitational flow of water from the surface. These are mainly subsoil channels. The most typical are the vertical ones (Fig. 7) with diameters that can reach up to one metre, the largest of which, as we shall explain below, can also be called subsoil shafts, which at the top develop into funnel-shaped mouths. Surface water that flows from the soil along the rocks collects in them. In cross-section the funnel-shaped mouths can take various shapes. They can be open, semicircular or nearly round. Their shapes are often the result of the permeability of the rock and the sediment contact along which the water flows downwards. Long, drawn-out formations of the mouth at less permeable connections causes the rock features to erode deeper into the rock. The water found its way through the rock less frequently and veritable funnels were shaped. Smaller and curving channels are formed at less permeable connections or when minor quantities of water collect on the sur-

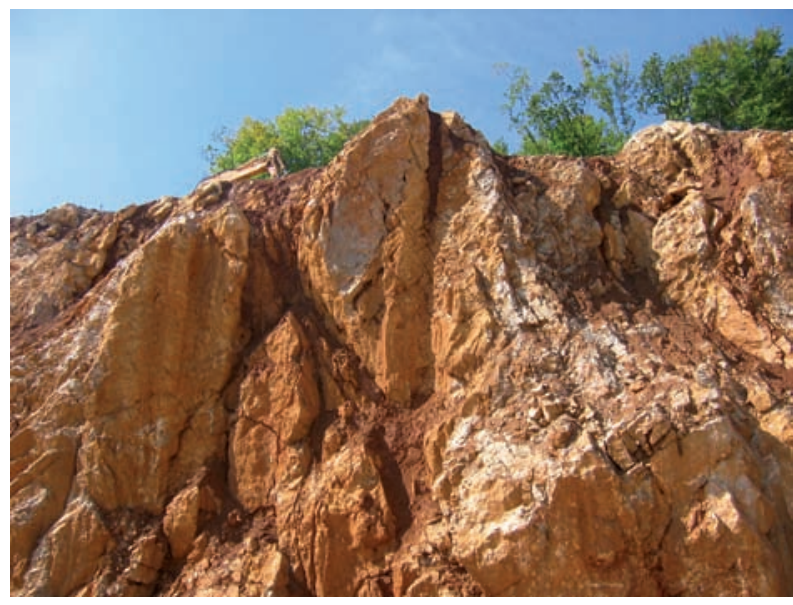

Fig. 7: Subsoil channels.

Sl. 7: Podtalni žlebovi.

face. This is characteristic for smaller pillars with tops that project out of the earth. Subsoil scallops are rare and generally indicate a well-permeable rock connection with the sediment that surrounds it, and moreover, we find elongated notches on the pillar walls, which are traces of water accumulation at the less permeable part of the connection and accelerated corrosion of the rock next to it.

Close below the surface where the rock is covered with soil the rock surface of the stone pillars is relatively smooth, while deeper, at the connection with the sediment that covers the surface, it is coarse and often has a configuration of rounded pendants. The rock there is weathered. The thickness of the weathered layer measures up to $1 \mathrm{~cm}$. It is soft when moist, but as it dries out after being exposed on the surface for a longer period and the water evaporates from it, it hardens. The state of weathering of the top layer of the rock is the result of the connection with the sediment, which is moist most of the time. The connection is relatively less permeable, and the water that does permeate it only slowly washes the solution. The connection with more permeable soil is correspondingly also more permeable.

\section{KARST HOLLOWS}

Uncovered hollows are generally the result of vertical water percolation through the epi-karst and the vadose parts of the aquifer. The shafts can be classified as hollow and those filled with sediment. The latter are termed subsoil due to the similarity of their features with subsoil rock, mainly with vertical subsoil channels.
The fifteen shafts (Fig. 8), vertical and mostly simple with only one in level, the deepest measuring $24 \mathrm{~m}$, three others deeper than $10 \mathrm{~m}$, while the rest were less deep, with diameters reaching up to 5 metres, but in most cases less, indicate here and there, greater permeability, allowing dense vertical water percolation due to 


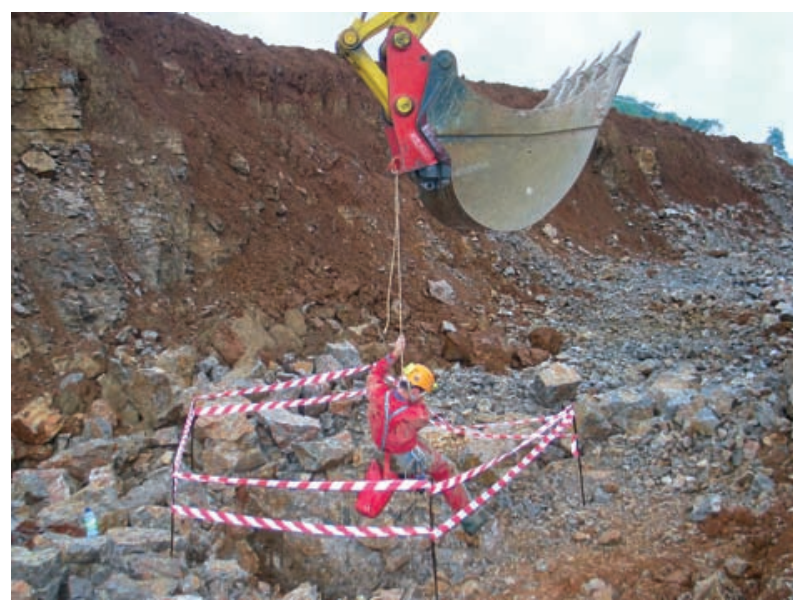

Fig. 8: Discovering of shaft.

Sl. 8: Odkrivanje brezna.

their expressed vertical cracks and vertical rock strata (Figs. 9, 10). The shafts occur among the subsoil karren and forests. They do not reach the surface. Their walls are carved with larger or minor vertical channels and often covered with a thin layer of sediment, which causes their thiny dissection (Slabe \& Knez 2004). The floors of

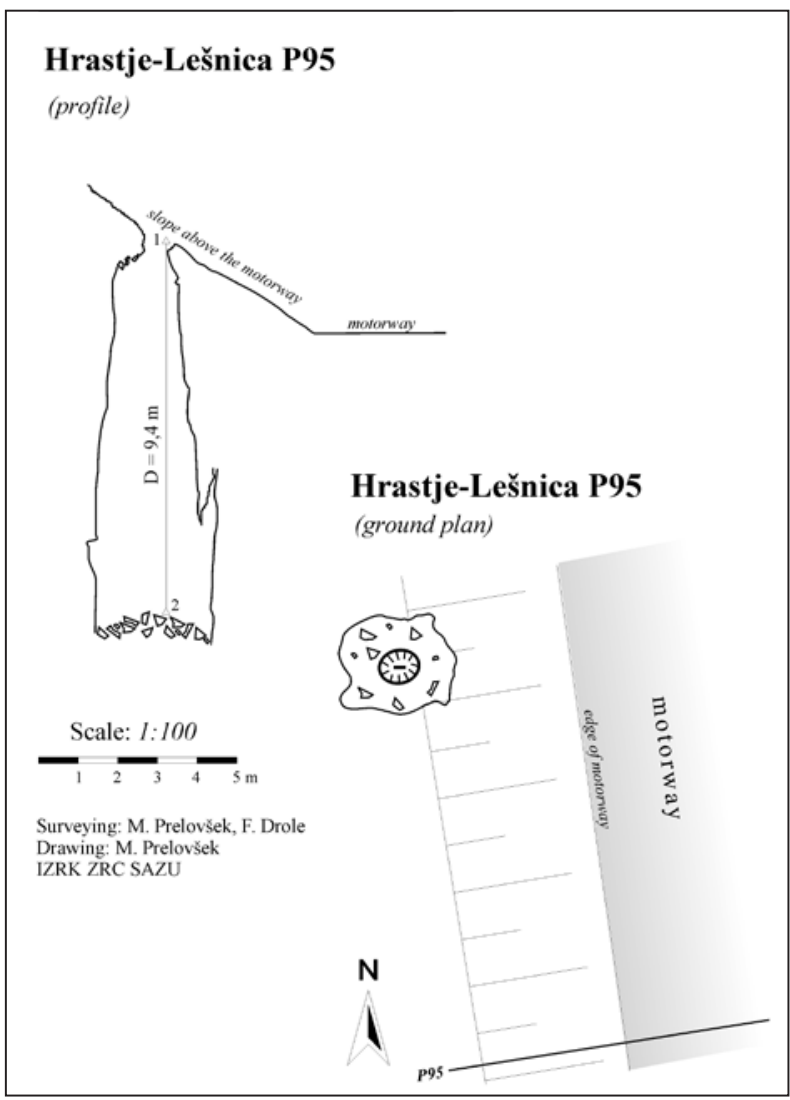

Fig. 9: Shaft on profile 95.

Sl. 9: Brezno na profile 95.

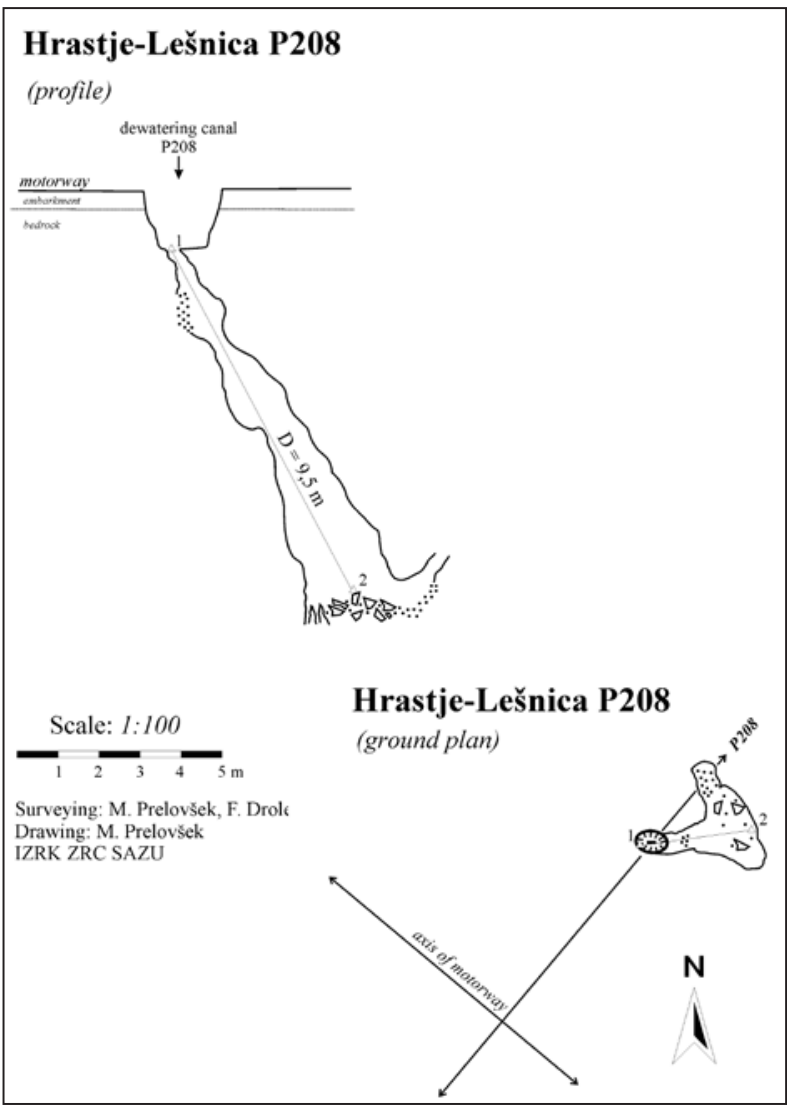

Fig. 10: Shaft on profile 208.

Sl. 10: Brezno na profilu 208.

the shafts are often covered by sediment or sediment fills their lower part.

Subsoil shafts are more or less vertical hollows, similar to ordinary shafts, through which water also percolates from the karst surface, but they are almost entirely filled with sediment, with only individual vertical sections

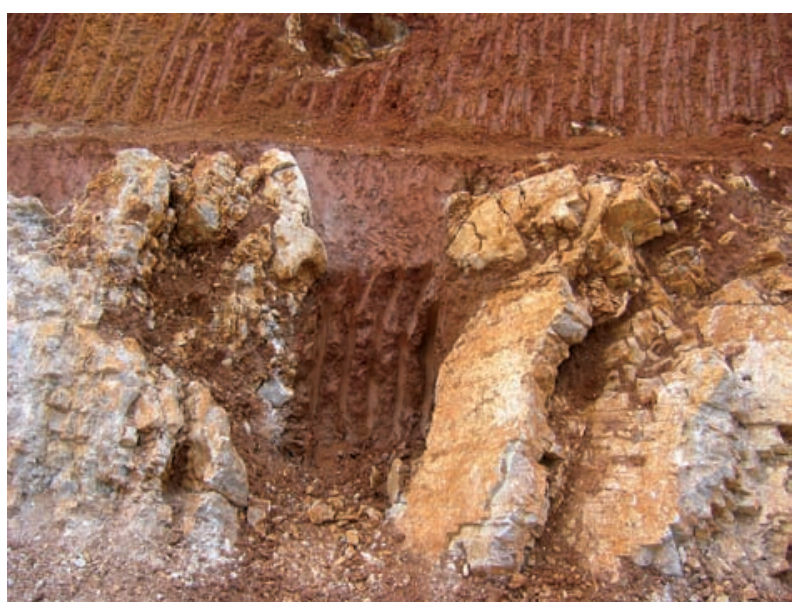

Fig. 11: Subsoil shaft along fault.

Sl. 11: Podtalno brezno vzdolž preloma. 
hollow. The water that flows through them deposits the sediment that covers the surface. Their cross-sections are more or less round or extended at the cracks and bedding planes. Their diameters reach two metres. Sediment filling facilitates the shaping of their periphery, and notches appear at less permeable connections. Subsoil shafts are formed at local dense flow of larger quantities of water. They can develop from subsoil channels. Their walls are carved with along-sediment rock features, which are the traces of formation at the connection with fine-grained sediment. With greater permeability in the karst interior, the subsoil shafts can be emptied.

Above-sediment channels often occur on horizontal bedding planes and in cracks, or networks of anastomoses, the traces of paragenetic stratification. Thus, temporarily flooded areas occur locally and the water, which carries fine-grained sediment and deposits, cuts its way upwards.

\section{CONCLUSION}

More and more, the unique natural heritage and development of the Dolenjska karst reveal themselves. The importance of the participation of karst researchers in planning major activities in the environment and monitoring the work has been demonstrated once again. Cooperation with the road constructors has set an excellent example for many years.

This time we were given the opportunity to follow the water precipitating into the epi-karst and the upper part of the vadose zone, which were shaped under a relatively thick cover of sediment and soil and where stone forests, shafts and subsoil shafts have been formed over large areas.

The scarcity of stone forests and special geomorphological karst features characteristic of this part of the karst (Knez et al., 2003) demand that we prepare guidelines for further planning of activities in the karst landscape.

\section{ACKNOWLEDGEMENT}

We would like to thank Mitja Prelovšek to draw figures 9 and 10.

\section{REFERENCES}

Knez, M., Slabe, T. \& Šebela, S. 2004: Karst uncovered during the Bič-Korenitka motorway construction (Dolenjska, Slovenia).- Acta carsologica 33/2, 7589, Ljubljana.

Knez, M., Otoničar, B. \& Slabe, T. 2003: Subcutaneous stone forest (Trebnje, Central Slovenia).- Acta carsologica 32/1, 29-38, Ljubljana.

Gams, I. 2004: Kras v Sloveniji v prostoru in času.Založba ZRC, 515 p., Ljubljana.
Pleničar, M., Premru, U. \& Herak, M. 1976: Osnovna geološka karta SFRJ 1:100000, list Novo mesto. Zvezni geološki zavod, Beograd.

Pleničar, M. \& Premru, U. 1977: Tolmač za list Novo mesto.- 61, Zvezni geološki zavod, Beograd.

Slabe, T., 1999: Subcutaneous rock forms.- Acta carsologica 28/2, 255-269, Ljubljana.

Slabe, T. \& Knez, M. 2004: Kraške podtalne skalne oblike.- Annales 14/2, 259-266, Koper. 
